\title{
THE ROLE OF TRANSFORMATION OF THE FUEL AND ENERGY SECTOR IN THE RUSSIAN SECURITY POLICY (IN RECORDS OF THE ECONOMIC SECURITY STRATEGY OF THE RUSSIAN FEDERATION UNTIL 2030)
}

\author{
Piotr MICKIEWICZ, PhD \\ Faculty of Social Sciences, Institute of Political Sciences \\ University of Gdansk, Poland \\ Email: piotr.mickiewicz@ug.edu.pl
}

\begin{abstract}
The article is a forecast of potential transformations of Russian policy resulting from the analysis of the provisions of the Energy Security Strategy until 2030. The author assumed that this document is a classic long-term development strategy, which was subordinated with five sectoral policies fundamental for Russia. This is a new approach to the construction of political activities, because so far it has been conducted through the mutual correlation of energy, transport, maritime, security and foreign policies. Apart from the first period of V. Putin's presidency, the energy policy was the leading policy, referring mainly to the organization of export of mining raw materials. Departure from this principle results from the fact that Russian economic and political politicians have been diagnosed with the consequences of lifting the ban on gas exports by the US authorities. The concept of counteracting this, as defined in the security threat, provides for an active pursuit of the export policy of transformed energy carriers and the expansion of export opportunities. The main emphasis was put on the creation of sustainable development processes in Russia, recognizing that the primary task will be the elimination of state development limitations. Nevertheless, the specificity of the impact of these processes means that Russia has decided to conduct a comprehensive policy of shaping the market for energy carriers, political and economic bonding of countries in the selected regions of the world and enabling the broadly understood transformations of the socio-economic sphere of the country. This policy is and will be implemented through the use of political, diplomatic, military and special means in the sphere of international influence, in internal politics through attempts to conduct the policy of sustainable development. The achievement of such defined strategic goals requires not only conducing of a deep technological transformation, but to obtain production capabilities that allow the creation of global gas prices and access to new sales markets. The decisive factors for the success of this concept are also the proper arrangement of mutual relations with China, i.e. the main importer and co-investor, and the "energy-related" new recipients. Significantly, this assumption changes both the scope of the subject of Russian domestic policy and the concepts of international influence.
\end{abstract}

Key worlds: Russia, security policy, economic security strategy, analysis 


\section{Introduction}

The Russian Federation does not have a formally announced state strategy. However, the invariable principle of Russian policy is the implementation of long-term, mutually correlated undertakings which are introduced on the basis of the provisions of sectoral horizontal strategies. Since the beginning of the $21^{\text {st }}$ century, the export of fossil fuels has been a factor creating the Russian development processes and deciding on potential countries. This conditioning has led to Russian policy being carried out in five mutually coordinated areas with five sectoral strategies defining its objectives. Their evolution is a consequence of the process of achieving individual partial objectives adopted in these documents. This peculiar strategic quintet was created by strategies: energy, transport and state security as well as maritime doctrine, which are supplemented by the so-called foreign policy concepts. Until 2017, the functions of the leadings strategies were played by the Concept of state security [2000-2004] and the Energy strategy [2004-2016]. The first of these documents should be seen in a wider dimension than the state security strategy. It defines the basic limitations determining the loss of the position of the superpower and the concepts of rebuilding the state's potential. It also contains the analyses that are the basis of the policy of restoring the cohesion of the state, centralizing power and taking control over the essential sectors of the Russian economy. While the energy strategy defines the objectives and principles of the mining, fuel and energy sectors as well as the vision of the mine fuels export policy, treated as an instrument of international influence and creating the Federation's economic policy. (Концепция национальной 2000, 06 Энергетической, Энергетическая Стратегия,). This vision underwent a far-reaching modification with the announcement of the export rules for LNG gas by the United States (Effect of Increased).

The American export policy has been recognized as the most serious threat to Russia's security and has transformed the principles of Russian strategic thought. In the place of the strategic quintet a new strategy emerged, which can be described as a long-term (13-year) development strategy. It has been detailed by four sectoral strategies, but it definitely has the nature of the most important state strategy document. Its position is also proven by the fact that the most important (leading) strategy so far, i.e. the energy strategy, has not been modified ${ }^{1}$. A significant part of the project's provisions of its amendment, mainly analyses and forecasts, has been included in the economic security strategy (Энергетическая Проект).

\section{Energy security strategy of the Russian Federation until 2030 as a strategy for the development of the state}

The strategy of economic security should be treated as the concept of the Russian reaction to the consequence of the abolition of the ban on the export of energy carriers by the US President. The decision is clearly perceived as a threat to the security of the state. At the same

\footnotetext{
In 2015-2016, the draft for its amendment was prepared. It was still to be the leading strategy and apply until 2035 (5 years longer than the remaining sectoral strategies). The last period of its validity (2030-2035) was supposed to be the time to evaluate its implementation and prepare the next 20-year version of this document.
} 
time, it is also a plan for the next modernization of the Russian economy, taking into account a number of social conditions and indicating the need for changes in the way the state is managed (О Стратегии P. II., point 12, subpoints 1-25). This document is a comprehensive, long-term vision of eliminating the negative effects of American policy, including a detailed action plan in the 12-13 year range. The strategic goal assumed is the creation of sustainable development processes in Russia, recognizing that out of the three most important threats to economic security [global socio-economic transformations, internal processes limiting the development possibilities of the state and social determinants] the last two are the most crucial. Nevertheless, the specificity of their impact means that Russia has decided to conduct a comprehensive policy through the use of political, diplomatic, military and special means in the sphere of international influence, implementing institutional and legal solutions and enabling the broadly understood socio-economic transformations (0 Стратегии, P. V, p. 32, 33). This process is strictly controlled by the central authorities, which are responsible for the right to create development programs and the control of their implementation processes. The central administration's task is also to control foreign investments in the armament and fuel and energy sector and the creation of mechanisms for immediate reaction to all uses of other discriminating mechanisms by other international players and imposing sanctions on Russian-speaking legal and natural persons, as well as branches of the Russian economy (О Стратегии, P. III, p. 16 subpoint 5). The role of the administrative apparatus and the armed forces is also to protect the rights and interests of Russian economic entities, especially in the Arctic continental shelf and global sea areas, and to build an integrated transport system. The sea connections with the catchment areas of the North Sea and the Baikal-Amur and the Trans-Siberian Railway were considered as priority investments in this area. Regions for which specific modernization and investment programs have been created are the Eastern Siberia, northern part of the Federation, the Far East, the North Caucasus, the Crimea and the Kaliningrad Oblast. An important element of these strategies are the social projects aimed at improving the education system, developing a lifelong learning system, reducing poverty and promoting employee mobility.

The fuel and energy sector was recognized as the sphere of economy which underwent fundamental transformations and at the same time stimulated socio-economic processes. The adopted formula of its transformation assumes the implementation of five processes:

- the necessary modernization of the existing infrastructure;

- implementation of new technologies for the processing of energy raw materials;

- replacing, as an export commodity, energy raw materials through the processed energy carriers;

- reducing the energy consumption of the Russian economy;

- reconstruction of the transmission system and the production of energy in a way ensuring sustainable development of all regions of the country (0 Стратегии, P. II, p. 14, 15).

The most important strategic goal, from the political point of view, was to change the structure of the energy carriers production. It was assumed that ultimately [until 2030] the production of oil, gas and light heating oil should increase by about 45-50 \% in relation to motor 
fuels and $30 \%$ in relation to liquefied gas. While the formula of modernization of the fuel and energy sector foresees implementation of projects modernizing and extending transmission systems, as well as extending the infrastructure of raw materials processing and conducting activities that increase the energy economics of domestic recipients [industries]. This goal was also assumed in the 2016 energy strategy draft, but only in the context of potential competition on the commodity trading market (Энергетическая Проект, p. 4.7 and 4.8). The technological transformation of the fuel and energy sector was recognized as a fundamental modernization task, aimed at extending the scope of production possibilities in relation to processed products, increasing efficiency and reducing the cost-consuming processes of raw material extraction, its processing and transmission with transport systems. Modernization undertakings have been correlated with a range of prosocial and pro-development activities, in the regional dimension and a modified concept of energy resources export.

The presented solutions have caused the maritime, transport and energy policies to be the spheres of economic policy that play a special role in the process of ensuring the economic security. However, their rank has changed, as maritime policy and, to a lesser extent, transport policy have become the leading policies. Their task is to provide opportunities for free trade and co-creation of political and economic processes, including the creation of political and economic links within the existing regional organizations [CIS, EAU, BRISC, SOW] and the co-creation of other forms of regional and supra-regional integration. They are to be used to expand the Russian export and investment opportunities (0 Стратегии, point 21, subpoints 2, 3, 5. Концепция внешней 2016 г. Р. I., p. 2. P. IV, p. 80-90). This economic expansion is to be supported also by international activity and active protection of national interests in the global dimension.

\section{The role of sectoral policies forming the strategic quintet in the assumptions of the economic security strategy of Russia}

The strategic goal of the Russian Federation until 2030 is to obtain the ability to change the production structure and acquire new sales markets by the Russian fuel and energy industry. The basic means to master them is not the product price but the type of products offered, mainly diesel oil, other oil products and LNG gas. In addition, this industry is to be the creator of pro-development activities in relation to social policy. It should be assumed that the priority investment projects in relation to transmission systems will be those that will enable the incorporation of the Russian strategic goals into the shape of energy policies of the most crucial importers and the assessment of the attractiveness of the market. The decision that the socalled new priority sales markets are to be the Asia and Pacific countries, and the main export commodity the liquefied gas has defined the scope of medium and short-term projects. Due to political reasons and in order to obtain funds for the implementation of adopted development projects, the transmission systems Nord Stream 2, Strength of Siberia 2, and Vankor-Pure will remain the leading investments. After the annexation of Crimea, it was also possible to return to the South Stream concept, which can be implemented for strictly political reasons, especially in order to use the fact of involvement in its implementation of a group of southern European 
countries. It seems reasonable to form the thesis about conducting investments enabling the exploitation of the Arctic resources of the continental shelf, but these activities will also have much greater political significance than the economic ones (Mickiewicz 2018, p. 292-310).

An important long-term goal of the Russia's energy policy will also involve conducting activities aimed at levelling the scale of export by new manufacturers and the growing importance of non-traditional hydrocarbons and renewable energy sources. Attempts will also be made to influence the processes of price setting and regulation of global energy markets (О Стратегии p. 5). Undertakings aimed at integrating Russian enterprises into energy investments in the selected countries, similar to the activities in Turkey and Iran [nuclear energy installations] and a wider use of German experiences [construction of gas power units] may also be carried out. Projects aimed at ensuring sustainable socio-economic development will also be implemented. They will be focused on projects ensuring continuity of supply, expanding the range of energy sources used, especially in regions with energy deficit and ensuring the stability of energy prices at the level resulting from the purchasing power of the society².

Based on these assumptions and the records of executive documents (Прогноз научнотехнологического), the following medium- and short-term objectives can be indicated. It should be assumed that they will be built in a horizontal arrangement, covering a 5-year implementation period [short-term objectives]. The main medium-term objective [to 2030] of Russian energy policy should be the gradual increase of export elasticity in the form of access to new markets and development of transmission networks and fuel terminals, including those capable of transporting LNG. This is defined both by the scope and the period of implementation of modernization and investment projects. It should be acknowledged that in the first period [until 2022] modernization processes will focus on successive increase of production efficiency, while investments will remain at the stage of preparations for implementation of specific innovative projects. They will be mainly conducted in the Far East, eastern Siberia, the northern continental shelf and the Yamal Peninsula. They will be concentrated not so much on increasing the output as the storage and processing of hydrocarbons, especially the development of liquefied gas processing systems. This conclusion can be drawn from the statements of the first deputy minister of energy, Алексейа Текслера, who believes that trading liquefied gas within a decade should be comparable to the volume of natural gas sales (Текслер). In terms of areas, these investments should be concentrated in the regions of Sakhalin, Irkutsk, Yakutia and Krasnoyarsk Krai, which results from current export concepts. Modernization processes will also include modernization, especially of the selected refineries, the transmission system Единая энергетическая система России (UPS) $)^{3}$ and undertakings allowing for the use of a wider range of local energy carriers,

\footnotetext{
2 One of the factors creating processes of sustainable social development was the assurance of the uninterrupted Energy supply at the level enabling individual recipients to fully use them. The project assumed artificial maintenance of the price of energy, where by 2035 the price of $1 \mathrm{kWh}$ for a retail individual was to amount to 9-10 US cents, according to the US dollar exchange rate from 2010. This solution was to reduce the cost of household and fuel expenses to $7 \%$ of its total income.

3 This is an essential element of the CIS synchronous transmission network with a generation capacity of
} 
especially water resources in relation to Siberia and the Far East and the use of solar energy 4 . In the second stage, the basic investment projects will include:

- projects allowing for the transmission of gas through two strands of the gas pipeline Strength of Siberia ${ }^{5}$;

- projects allowing the full use of the Amur Gas Processing Plant (Belogorsk);

- expansion of infrastructure for LNG exports on the Jamaican Peninsula and Sakhalin6;

- construction of the Amur gas refinery?

Another of the medium-term objectives is to obtain opportunities to trade in fuel oil and electricity itself. This turnover will be focused in the Commonwealth of Independent States and Continental Asia. Obtaining this ability, especially in relation to heating oil trade, also depends on the strictly political factors. The condition is to recognize China not only as the importer, but also as the transit state participating in this exchange. However, with regard to energy export and unprocessed energy resources, it is a prerequisite to maintain the existing forms of cooperation with Turkey and Kazakhstan. With regard to Turkey, it is necessary to obtain Istanbul's acceptance of Russian forms of activity in the Mediterranean and Black Sea region, especially the energy bonding of this region through the construction of the storage and transmission infrastructure in this territories of these countries. An additional factor, closely related to the above issue, will be the scale of exports of Russian energy technologies and involvement in the construction of Turkish nuclear power plants. Kazakhstan plays a key role in creating the energy cooperation of the CIS countries. Without its participation, it is not possible to operate the Eurasian Economic Space, and what follows is the common energy space. Cooperation within the CIS energy space will continue in areas such as production and export of crude oil, natural gas and coal, trade in petroleum products and electricity, however, Russia will definitely consider the turnover of processed products and electricity as its priorities, while at the same time expanding the share of other countries of the Community in the export of energy resources. However, it will be run by existing transmission systems, which will enable the control of the scale of exports and, indirectly, the widening of economic integration.

The above-mentioned objectives of the energy security strategy and modernization and investment plans in relations to the energy and fuel sectors shape the format of remaining policies of the strategic quintet. The transport policy will be shaped in correlation with the adopted diversification projects of export directions of energy carriers and its predicted scale of the size

300 gigawatts, serving 280 million recipients. The Russian part is made up of six integrated regional transmission systems.

4 In 2015-2017, 19 solar power plants with a total capacity of 210 MW were opened in Russia.

5 The construction is to be completed by December 20,2019, and the contract assumed delivery of 38 billion $\mathrm{m}^{3}$ of gas annually to China.

6 Currently, the largest recipients of liquefied gas are Japan and South Korea. The gas terminals of Yamal LNG, (Vladivostok LNG) and Sakhalin LNG will provide wider export opportunities.

7 The Amur refinery will be the largest gas processing plant in Russia with a capacity of 42 billion $\mathrm{m}^{3}$ of gas annually. The plant will ultimately also produce 60 million $\mathrm{m}^{3}$ annually. 
of export. Transport and transmission projects should also play the role of an instrument binding economically on transit countries with Russia. This possibility is created by the initiative of the Common Economic Space (0 Стратегии экономической, p. III p. 2). The political dimension of this policy is brought down to the incorporation of Russian transport and transmission systems into the global transport system, which is expected to increase the possibilities of shaping the international transport policy (0 Стратегии экономической p. IV Цели, 3, 4).

The manner of organizing transport assumes its conduct in the area of the Federation in various forms, including the use of Russian ports and sea carriers as well as the Trans-Siberian Railway. This assumption defined the scope of the Federation's maritime policy. The detailed objectives have been defined for each of the so-called Regional Directions of the National Maritime Policy and were correlated with the other objectives of the maritime policy and national security.

\section{Table 1.}

\section{The objectives of maritime activities on the areas of Regional Policy of the National Maritime Policy related to the plans for the export of energy carriers}

\begin{tabular}{|l|l|}
\hline Direction & $\begin{array}{l}\text { Objectives of the maritime activity in particular Directions of Maritime Policy and } \\
\text { their water bodies }\end{array}$ \\
\hline Atlantic & $\begin{array}{l}\text { Baltic and North Sea } \\
\text { - ensuring the continuity of maritime communication connections with Russia } \\
\text { across the Baltic Sea } \\
\text { - development of port infrastructure, allowing to increase export possibilities of } \\
\text { gas and hydrocarbons and the use of inland connections with Baltic ports } \\
\text { construction of submarine transmission and energy systems to the Kaliningrad } \\
\text { Oblast }\end{array}$ \\
\cline { 2 - 3 } & $\begin{array}{l}\text { Mediterranean Sea } \\
\text { - development of maritime and energy infrastructure in the Crimea and the Kras- } \\
\text { nodar Krai } \\
\text { the use of the possibility of exporting energy carriers through the Black Sea }\end{array}$ \\
\hline Arctic & $\begin{array}{l}\text { construction of gas transmission complexes in the Barents and Kara seas region } \\
\text { intensification of the activities of naval forces around the Svalbard archipelago, } \\
\text { Land of Franz Joseph, New Lands and Wrangel Island }\end{array}$ \\
\hline Caspian & $\begin{array}{l}\text { limitation of maritime activities of third countries through the use of the law of } \\
\text { the sea and multilateral agreements with maritime powers }\end{array}$ \\
\hline & $\begin{array}{l}\text { creation of the oil and gas extraction and transmission system in the Russian } \\
\text { part of the Caspian Sea }\end{array}$ \\
\hline
\end{tabular}




\begin{tabular}{|l|l|}
\hline Pacific & $\begin{array}{l}\text { construction of submarine transmission systems, including the LNG gas ter- } \\
\text { minal and the Sakhalin - Tatar Strait - Komsomolsk-on-Amur - Khabarovsk } \\
\text { - Vladivostok gas pipeline } \\
\text { - integration of the region with the Asian economic space and creation of perma- } \\
\text { nent sea connections with the Far East ports, among others in order to use the } \\
\text { transit from Southeast Asia to Europe via the Trans-Siberia Railway }\end{array}$ \\
\hline Indian Ocean & $\begin{array}{l}\text { obtaining the possibility of temporary presence of the Navy of the Russian Fed- } \\
\text { eration in the Indian Ocean (intermediate objective, enabling possible export } \\
\text { along the southern coast of Asia, including to India) }\end{array}$ \\
\hline
\end{tabular}

Source: own study based on Морская доктрина 2015, p. III, p. 49-72.

The condition for using sea transport for export of energy carriers is the reconstruction of the existing port infrastructure and increasing the capacity of the fleet filling the so-called systematic activities on sea areas, especially ice-breakers and tugs. While ensuring the safety of vessels transporting the energy carriers by the sea requires conducting sea activity, focused on the control of the selected water bodies. These objectives have been determined by the maritime doctrine, while the concept of carrying out basic investments in port infrastructure has been recognized as one of the most important tasks carried out under the investment programs specified in the Economic Security Strategy. As part of the maritime policy, activities will be carried out to ensure transport safety and the possibility of exploring newly estimated or discovered deposits. An important part will involve activities aimed at creating a specific legal regime on sea areas and combating criminal offenses at sea (Морская доктрина 2015, p. 16-17). This should lead to sanctioning both the right to exploit resources in disputed areas, eliminating criminal threats that could be used to attempt to legitimize the military presence of other international players in the water bodies crucial for Russia ${ }^{8}$.

Activities carried out within the framework of the security policy related to the export of energy carriers have been focused in the Arctic, the Caspian and Black Sea, and the Baltic region. The adopted vision of conducting exports from Siberian fields and the possible exploitation of Arctic resources makes the Arctic and Atlantic bodies the most important areas of military activity of the Direction of the National Maritime Policy. The forces deployed in this area are to ensure the possibility of achieving Russian interests located in the Arctic, in particular enabling the conduct of research works allowing the estimation and assessment of the possibility of taking up extraction of energy resources. The second task is to maintain control over the use of the Northern Shipping Route, which also assumes levelling the potential for operating on the Antarctic Ocean of naval forces of other countries (0 Военной доктрине, Морская доктрина 2015, p. III, p, 49-56). This task was entrusted to the forces of the Northern Fleet, whose modernization process is to allow the control of this reservoir. This is evidenced by investment

8 In this way, Russia and, above all, China has used the policy of combating piracy in the Gulf of Aden. This activity has been used to sanction the presence of the military forces of these countries on both sides of the Suez Canal, that is, the regions controlled so far only by the Americans. 
projects in the form of the creation of a system of military airports and bases for the stationing of naval forces, the development of technical observation systems and the structure of forces. The fleet is equipped with oceanic icebreakers with atomic propulsion and submersible vessels, which ensures continuous presence of Russian units in these waters (regardless of the state of icing of the reservoir) 9 .

\section{Table 2.}

Expansion of infrastructure around the arctic military bases.

\begin{tabular}{|c|c|c|}
\hline Region & Forces deployed & Tasks \\
\hline Alakurti & $\begin{array}{l}\text { reinforced motorized brigade with } \\
7000 \text { soldiers } \\
\text { airport }\end{array}$ & $\begin{array}{l}\text { support of potential activities in the } \\
\text { Arctic }\end{array}$ \\
\hline Kotielnyj & $\begin{array}{l}\text { warships } \\
\text { icebreakers } \\
\text { airport }\end{array}$ & $\begin{array}{l}\text { Control of shipping lanes in the Bering } \\
\text { Strait } \\
\text { presence in the Antarctic Ocean }\end{array}$ \\
\hline Temp & airport for transport planes & $\begin{array}{l}\text { logistics support of activities in the } \\
\text { Arctic }\end{array}$ \\
\hline Tkisi & $\begin{array}{l}\text { airport for patrol, reconnaissance } \\
\text { and interceptor fighters }\end{array}$ & $\begin{array}{l}\text { control of water bodies around the Arctic } \\
\text { air patrols and the possibility of destruc- } \\
\text { tion of objects in Alaska }\end{array}$ \\
\hline Anadyra & airport for fighters & $\begin{array}{l}\text { air patrols and the possibility of destruc- } \\
\text { tion of objects in Alaska }\end{array}$ \\
\hline Wrangel Island & military base (under construction) & monitoring the Bering Strait \\
\hline Land of Franc Joseph & military base (under construction) & $\begin{array}{l}\text { control of the situation in the } \\
\text { north-western part of the Barents Sea }\end{array}$ \\
\hline Murmansk & $\begin{array}{l}\text { place of stationing a reinforced } \\
\text { motorized brigade and a maritime } \\
\text { brigade }\end{array}$ & conducting combat operations \\
\hline Arkhangelsk & $\begin{array}{l}\text { place of stationing a reinforced } \\
\text { motorized brigade }\end{array}$ & conducting combat operations \\
\hline $\begin{array}{l}\text { Yamalo-Nenets Au- } \\
\text { tonomous Okrug }\end{array}$ & $\begin{array}{l}\text { place of stationing a maritime } \\
\text { brigade }\end{array}$ & conducting combat operations \\
\hline New Land & $\begin{array}{l}\text { anti-aircraft defense unit with } \\
\text { S400 Triumf rockets } \\
\text { Pancyr S-1 artillery and missile } \\
\text { sets }\end{array}$ & $\begin{array}{l}\text { defense of territory and control of the } \\
\text { area along with adjacent sea reservoirs }\end{array}$ \\
\hline
\end{tabular}

Source: own study

9 The ground forces deployed in the area, especially Special Forces, gradually gain the ability to conduct operational activities in any Arctic region in response to attempts to limit the Russian interests. 
The plans to export energy carriers and exploit arctic resources were also subordinated to the militarization of the Kaliningrad Oblast and the formula of conducting military activity in the Black Sea and the Caspian regions. The structure of forces deployed in the Kaliningrad District allows their use as a possible reserve for individuals undertaking activities to protect Russian interests in the northern waters of Europe and the Arctic. The main task is to carry out a policy of levelling all limitations of Russian concepts of exploitation and use of the Arctic and areas around the Arctic to develop pro-export sectors of the Russian economy (Морская доктрина $p$. 10-13). This purpose is served both by the expansion of military potential and by the formula of activities on sea areas and their airspace. The Caspian and Black Sea policy, on the other hand, adopts an economic and military dimension but its aim is to block the possibility of building alternative routes for the transport of Caspian energy resources and to gain the possibility of controlling economic processes in the region. An element of this policy is the development of the sea-river connections network and the construction of multi-modal connection systems of the Caspian Sea - Mediterranean Sea, which allows the Caspian countries to conduct the intercontinental exchange of goods, but controlled by Russia (Морская доктрина р. 17-27).

Adoption of Asia and South America as the target area of the export of energy carriers has also defined the formula of diplomatic activity and the manner of conducting foreign policy. The creation of external conditions for the development and increase of competitiveness of Russia economies as well as the elimination of negative transformations of the global system of extraction and trading of energy carriers should be considered as sectoral goals of the international influence of Russia. US activity on the market of energy carrier exporters, price fluctuations and potential crises in the regions of their extraction and economy as well as the strengthening of the position of the state as a global economic player should be considered as such (Концепция внешней p. I, р. 2). In this formula, the policy of exporting energy carriers will be used to shape the international order in the regional dimension and in cooperation with the countries identified as desirable partners. The countries forming the BRICS, SOW, APEC and the Russia-India-China triangle were considered as such (Концепция внешней, subpoint I.4, p. IV. , subpoints 42, 46, 48 e, 49, 51, 52, 53, 67 ).

\section{Summary}

In summary, it should be assumed that the Strategy of economic security until 2030 is a horizontal development strategy for Russia. The state policy was adapted to its objectives in relation to the selected functional spheres of the state. The decisive factor for the success of this strategy is the possibility of implementing the adopted concept of energy carriers export, conditioned additionally by the successful modernization and reconstruction of the mining and fuel and energy sectors. Other sectoral policies are to play a serving role towards activities carried out under the Strategy of economic security. The land and sea transport system is to provide export opportunities and transfer of raw materials to processing refineries. However, the primary task will be to provide export opportunities, both for obtaining new (non-traditional, as defined in the Russian documents) recipients, as well as economic and energy binding of 
transit states and importers. The priority will be to use the land transmission systems in the continental Asia. However, this requires the possibility of blocking, alternative to Russian transmission systems, the concept of export of energy resources from Central Asia. The prospective implementation of export assumptions concerning the processed energy carriers will result in a significant transformation of the maritime policy. Currently, treating it as the priority task, i.e. guaranteeing security in maritime areas belonging to Russia, it will be an additional goal of this policy. The sea activity will focus on obtaining the opportunities to operate and use the world's ocean. In particular, Russia's enforcement of the right to freely set up transmission systems on the open sea and the construction of artificial islands. In order to achieve these goals, the participants will be able to participate or conduct independent activities focused on neutralizing security threats on sea areas and demonstrating power in the areas of locating national interests (Морская доктрина). Thus, counteracting Russia's export policy is to meet with the immediate political and military reaction (Стратегия национальной безопасности Российской Федерации до 2020 года, 41-43). This is evidenced by both the reform of the armed forces and the issue of conducted exercises of Russian troops. The combat capabilities they acquire, especially for rapid dislocation in the selected regions of the Federation, expanding the capabilities of sea and air forces in the international airspace and the open sea, or attempts of permanent presence in the South Pacific, Indian Ocean and the North Atlantic and the Mediterranean authorize the statement that they can be used for activities in the event of occurrence of the raw material war (provoked by the Federation). Conducted both on the sea areas and in Central Asia.

\section{References}

Министерство Энергетики Российской Федерации (2009), Энергетическая стратегия России на период до 2030 года, Распоряжение Правительства РФ от 13 ноября 2009 г. № 1715-p. https://minenergo.gov.ru/node/1026. (Accessed: 10.04.2018)

Министерство Энергетики Российской Федерации (2015), Энергетическая стратегия России на период до 2035 года (Проект) http://www.energystrategy.ru/ab_ins/source/ES2035_09_2015.pdf. (Accessed: 08.12.2018)

Министерство Энергетики Российской Федерации (2016), Прогноз научнотехнологического развития отраслей топливно-энергетического комплекса России на период до 2035 года, утверждена Министром Энергетики Российской Федерации. https:// minenergo.gov.ru/view-pdf/6366/67618 (accessed: 12.10.2018)

Правительство Российской Федерации (2003), 06 Энергетической стратегии России на период до 2020 года, Распоряжение Правительства РФ от 28.08.2003 № 1234-р Источник: http://www.rosteplo.ru/Npb_files/npb_shablon.php?id=25 (accessed: 12.09.2018)

Президент Российской Федерации (2000), Концепция национальной безопасности Российской Федерации, http://nvo.ng.ru/concepts/2000-01-14/6_concept.html. (Accessed: 10.01.2019)

Президент Российской Федерации (2016), Концепция внешней политики Российской Федерации, утверждена Президентом Российской Федерации 30 ноября 2016 г. http:// 
www.mid.ru/foreign_policy/news/-/asset_publisher/cKNonkJE02Bw/content/id/2542248. (Accessed: 10.01 .2019$)$

Президент Российской Федерации (2014), 0 Военной доктрине Российской Федерации, Указ Президента Российской Федерации от 25.12 .2014 г. http://pravo.gov.ru/proxy/ips/? docbody $=$ \&nd $=102135800$ \& intelsearch $=\% E F \% F 0 \% E E \% F 4 \% E 8 \% E B \% E 0 \% E A \% F 2 \% E 8 \% E A$ \%E0+\%FD\%EA\%F1\%F2\%F0\%E5\%EC\%E8\%E7\%EC\%E0+\%E8++\%F2\%E5\%F0\%F0\%EE\%F\%E8 $\%$ E7\%EC\%E0 (accessed: 12.09.2018)

Президент Российской Федерации (2017), 0 Стратегии экономической безопасности Российской Федерации на период до 2030 года, Указ Президента РФ от 13 мая 2017 г. № 208 http://www.garant.ru/hotlaw/federal/1110794/\#ixzz4j2sKQ0BC_(accessed: 12.09.2018)

Президент Российской Федерации (2015), Морская доктрина Российской Федерации, Утверждена Указом Президента Российской Федерации от 26 июля 2015 года, http://static. kremlin.ru/media/events/files/ru/uAFi5nvux2twagiftS5yrlZUVTJan77L.pdf

U.S. Energy Information Administration (2014), Effect of Increased Levels of Liquefied Natural Gas Exports on U.S. Energy Markets, Independent Statistics \& Analysis, DC 20585, Washington October 2014, https://www.eia.gov/analysis/requests/fe/pdf/Ing.pdf. (Accessed: 10.04.2018)

Текслер А. (2017), Важны технологические компетенции, „Коммерсант”, 15.05.2017. 